\title{
Effect of Mulching on Hydrothermal Regime and Fruit Yield of Tomato (Lycopersicon esculentum Mill)
}

\author{
Sunil A. Nair* \\ Department of Plantation crops and Spices, College of Horticulture, Kerala Agricultural \\ University, Vellanikkara, Thrissur, Kerala, KAU PO 680656, India \\ *Corresponding author
}

\section{A B S T R A C T}

\section{Keywords}

Mulching, Soil temperature, Soil moisture,

Hydrothermal regime, Polyethylene, Mulch levels, Fruit yield

\section{Article Info}

Accepted:

10 January 2018

Available Online:

10 February 2018
Four mulch types (black polyethylene mulch, transparent polyethylene mulch, straw mulch and un mulched) were evaluated to assess the effect caused on soil temperature, soil moisture and fruit yield of tomato. The experiment was carried out during Kharif season under midhills condition of Himachal Pradesh. The results showed that application of polyethylene mulches significantly influenced the hydrothermal regimes viz., soil temperature and soil moisture. Transparent polyethylene mulched plots of (TPM) recorded an increase in maximum temperature and Black polyethylene mulched plots (BPM) showed increase in minimum temperature as compared to un mulched plots of tomato. Data on soil moisture revealed maximum soil moisture conservation under black polyethylene mulch followed by transparent polyethylene mulch and straw mulch. Black polyethylene mulch recorded $13.08 \%$ higher soil moisture content as compared to un mulched plots. Observations on fruit yield/plot showed yield increase of $50.66 \%$ in plots mulched with black polyethylene mulch over un mulched plots followed by transparent polyethylene mulch. Amongst the various treatments, intra-row aligned plots of 50 micron thickness of BPM (M2) recorded the maximum fruit yield (38.67 kg/plot)

\section{Introduction}

Crop production is closely related to the varietal type, region, weather conditions of the place, nutrient status, soil productivity and management practices which may influence the microclimate of the crop. Mulching; a important management practice have been reported to improve the growth and yield of vegetable crops through changes in the hydrothermal regime of the soil. Polyethylene mulches have been reported to improve soil moisture status (Vinuta et al., 2016), increase in soil temperature and reduced light availability (Bakht et al., 2014) control weeds (Abul-Soud et al., 2010) and greater marketable yield (Rajablariani et al., 2012) in vegetable crops. Tomato (Lycopersicon esculentum Mill) one of the important members of the solanaceaae family is widely grown crop throughout the world. In India the crop is cultivated in an area of 760.1 thousand hectares and 16,385 thousand metric tonnes with a productivity of 24.2 metric tonnes/hectare (Anonymous, 2016). In Himachal Pradesh, tomato is one of the major 
off season crop cultivated mostly in the low and mid hills. As such the farmers fetch a premium price by supplying tomatoes during the off season to the plains. Besides diseases and insect pests, weeds are a major contributor to overall losses and problem in its cultivation. The first 3-6 weeks after transplanting is the critical period for weed competition in tomato cultivation and unrestricted weed competition may reduce tomato fruit yield by 40-60\% (Adigun, 2005). Various workers have reported the beneficial effect of both organic mulches viz., straw and inorganic mulches viz., polyethylene mulches on growth and yield parameters in tomato and alteration in the hydrothermal regime of the crops and suppression of weed growth. However research on the influence of various mulch thickness and alignment of polyethylene mulches and its comparison with conventional straw mulch on plant biometrics is limited. In view of the prevalent yield constraining factors and beneficial aspects of different mulches as reported by various workers a field experiment was conducted to examine the role of mulches on hydrothermal regime viz., soil temperature and soil moisture, weed count and fruit yield of tomato var. naveen.

\section{Materials and Methods}

\section{Experimental site}

The field study was conducted during the Kharif season of 1998 at the Department of Vegetable crops, Dr. Y.S. Parmar University of Horticulture and Forestry Nauni, Solan Himachal Pradesh. The experimental farm situated in Nauni is $15 \mathrm{~km}$ away from Solan at $30{ }^{0}-51$ 'N latitude and about $77^{\circ}-11^{\prime} \mathrm{E}$ longitude. The place has a elevation of $1260 \mathrm{~m}$ above mean sea level and falls under the mid hill zone of Himachal Pradesh. The climate of Nauni is sub temperate to sub-tropical, May and June being the hottest months and December to January the coldest months.

\section{Soil Analysis}

Composite soil samples were collected at 0-15 $\mathrm{cm}$ depth before transplanting from each replication and analysed for their physicochemical properties. Physico-Chemical properties of soil revealed the soil as silt-loam in texture, medium in $\mathrm{N}$ content, high in $\mathrm{P}_{2} \mathrm{O}_{5}$ and medium in $\mathrm{K}_{2} \mathrm{O}$ content with a ${ }_{\mathrm{P}} \mathrm{H}$ content of 6.83 .

\section{Treatment details}

The experimental design was randomized block design and treatments were split into orthogonal components so that the different classes of effect to which the experimental material is subject was capable of direct and separate estimation. The treatments comprised of 10 mulch material combinations with mulch thickness and alignment and replicated thrice. The different treatments were M0- un mulched (UM), M1- Straw mulch (SM), M2m2 -Black polyethylene mulch (BPM) 30 micron $(\mu)$ inter- row), M2m3 (black polyethylene mulch $30 \mu$ intra- row), M2m4 (black polyethylene mulch 50 micron $(\mu)$ inter- row) M2m5 (black polyethylene mulch $50(\mu)$ intra- row), M3m6transparent polyethylene mulch (TPM) $30(\mu)$ inter-row), $\mathrm{M} 3 \mathrm{~m} 7$ transparent polyethylene mulch $30(\mu)$ intra-row), M3m8 (transparent polyethylene mulch $50(\mu)$ inter-row), M3m9 (transparent polyethylene mulch $50(\mu)$ intrarow). The data was analysed by procedure followed by Panse and Sukhatme (1985) and results interpreted on basis of F-test and treatments tested at $5 \%$ level of significance.

\section{Cultural practices and observations}

Seeds were sown in nursery beds in the month of March and seedling transplanted on first week of May at 4-5 leaf stage. 18 seedlings were transplanted at a spacing of $90 \times 30 \mathrm{~cm}$ in a plot size of $4.86 \mathrm{~m}^{2}$. Fertilizer management was done as per 
recommendations. Mulching was done prior to transplanting in May1998. Straw mulch (SM), polyethylene mulches viz., Black (BPM) and Transparent (TPM) of 30 and $50 \mu$ thickness each were used to cover the experimental plots along with their method of placement i.e. inter row and intra row. Minimum space of at least 4 inches was maintained between 2 successive strips to allow for transplanting. Soil moisture content (\%) was determined from $0-15 \mathrm{~cm}$ soil depth by gravimetric method by drying soil samples in aluminium boxes in oven at $105^{\circ} \mathrm{C}$ for $48 \mathrm{hrs}$ and data were recorded at fortnightly interval. Soil temperature was observed by fixing platinum resistance thermometers at $5,10 \mathrm{~cm}$ depth. The temperatures in ${ }^{0} \mathrm{C}$ were recorded daily for minimum at $0730 \mathrm{hrs}$ and maximum at 1430 hrs. The total yield of marketable fruits harvested from net plot area was recorded and expressed in $\mathrm{kg} /$ plot.

\section{Results and Discussion}

\section{Soil temperature}

As evident from figure 1 and 2 application of different mulch materials significantly influenced the soil thermal regimes at both 5 and $10 \mathrm{~cm}$ depth. Soil temperature was found to be higher in plots mulched with TPM, BPM and UM plots than the air temperature whereas it was lower in SM plots. TPM raised the maximum temperature at $1430 \mathrm{hrs}$ by 1.5 to $4.5^{\circ} \mathrm{C}$ and minimum temperature at 0730 hrs by 1.5 to $4.4^{0} \mathrm{C}$ over UM plots. The reason attributed is that TPM permits the incoming short wave radiation to pass through but its transmissivity to long wave radiation is highly reduced due to formation of water droplets on its lower surface. In contrast, BPM did not alter appreciably the maximum temperature however it caused an increase in minimum temperature by 1.0 to $3.1^{\circ} \mathrm{C}$ over un mulched plots. This may be due to the fact that BPM absorbs much of the incident radiation due its black colour but transmits less energy to the soil surface owing to bad conducting air between mulch and the soil surface. In SM plots; a decrease of 0.4 to $3.5^{\circ} \mathrm{C}$ in maximum temperature and increase of 0.5 to $2.7^{\circ} \mathrm{C}$ in minimum temperature was noted over UM plots respectively. Similar observations were noted by Eruola et al., (2012) under grass mulch as compared to UM plots in yams. The decrease in the maximum temperature under SM may be due to the higher albedo as a result of greater conversion of solar energy into evaporative flux and increase in the diffusion path of heat transfer to the soil. The increase in the minimum soil temperature may be due the reduction in the negative flux from the soil. Similar observations on modification of the soil thermal regimes have been explained in light of views expressed by Ham et al., (1993) and Gupta and Acharya (1993). These results are in consonance with the findings of Ramakrishna et al., (2006) who has reported that polyethylene mulch increased the soil temperature by about $6{ }^{\circ} \mathrm{C}$ at $5 \mathrm{~cm}$ depth and 4 ${ }^{0} \mathrm{C}$ at $10 \mathrm{~cm}$ depth in groundnut. Research on straw mulching in tomatoes by Kosterna (2014) revealed an increase of $1.3{ }^{\circ} \mathrm{C}$ at 0800 hrs and $1.7^{\circ} \mathrm{C}$ at $1400 \mathrm{hrs}$ as compared to un mulched. Liu et al., (2014) and Abhivyakti et al., (2016) reported a increase of $1-3{ }^{0} \mathrm{C}$ in maize and $1-10{ }^{0} \mathrm{C}$ in tomato respectively in plots mulched with polyethylene mulches as compared to un mulched. In the present studies soil temperature noted at $10 \mathrm{~cm}$ depth followed similar trend as $5 \mathrm{~cm}$ depth.

\section{Soil moisture \%}

The data on soil moisture content under different mulch materials recorded during the cropping period for $0-15 \mathrm{~cm}$ soil depth is shown in table 1 . The data revealed that the mulch material under investigation was found effective in conserving soil moisture. Figure 1 shows the mean soil moisture recorded under mulches in the order $\mathrm{BPM}>\mathrm{TPM}>\mathrm{SM}>\mathrm{NM}$. 
Table.1 Effect of mulch materials on soil moisture content at $0-15 \mathrm{~cm}$ depth under different mulch materials for the quarterly period (May-August)

\begin{tabular}{|l|l|l|l|l|}
\hline Date & UM & SM & BPM & TPM \\
\hline 17 May & 15.20 & 16.00 & 18.60 & 18.31 \\
\hline 02 June & 15.18 & 16.20 & 18.39 & 17.87 \\
\hline 18 June & 16.20 & 16.80 & 20.35 & 19.30 \\
\hline 02 July & 16.50 & 17.00 & 19.80 & 19.00 \\
\hline 17 July & 17.30 & 17.70 & 18.34 & 18.13 \\
\hline 2 August & 18.46 & 18.60 & 19.39 & 18.87 \\
\hline 17 August & 16.00 & 16.38 & 17.29 & 16.84 \\
\hline Total & 114.84 & 118.68 & 132.16 & 128.32 \\
\hline Mean & 16.41 & 16.95 & 18.88 & 18.33 \\
\hline \% increase & - & 3.18 & 13.08 & 10.47 \\
\hline
\end{tabular}

Figures in \%, UM = Un-Mulched, SM = Straw Mulch, BPM - Black Polyethylene Mulch, TPM - Transparent Polyethylene Mulch

Table.2 Effect of mulch materials on fruit yield/plot

\begin{tabular}{|c|c|c|c|c|c|c|c|c|}
\hline \multirow{2}{*}{$\begin{array}{l}\text { Thickness } \\
\text { Mulch }\end{array}$} & \multicolumn{2}{|c|}{$30 \mu$} & \multirow[b]{2}{*}{ Mean } & \multicolumn{2}{|c|}{$50 \mu$} & \multirow[b]{2}{*}{ Mean } & \multirow{2}{*}{$\begin{array}{l}\text { Overall } \\
\text { mean }\end{array}$} & \multirow{2}{*}{$\begin{array}{l}\% \text { yield } \\
\text { increase }\end{array}$} \\
\hline & $\begin{array}{l}\text { Inter- } \\
\text { row }\end{array}$ & $\begin{array}{l}\text { Intra- } \\
\text { row }\end{array}$ & & $\begin{array}{l}\text { Inter- } \\
\text { row }\end{array}$ & $\begin{array}{l}\text { Intra- } \\
\text { row }\end{array}$ & & & \\
\hline $\begin{array}{l}\text { Transparent } \\
\text { (M3) }\end{array}$ & 30.83 & 33.10 & 31.97 & 30.33 & 34.33 & 32.33 & 32.15 & 44.54 \\
\hline Black (M2) & 34.57 & 34.60 & 34.59 & 36.73 & 38.67 & 37.70 & 36.14 & 50.66 \\
\hline Straw (M1) & & & & & & & 22.90 & 22.14 \\
\hline $\begin{array}{c}\text { Un mulched } \\
(\mathrm{M} 0)\end{array}$ & & & & & & & 17.83 & - \\
\hline \multicolumn{9}{|l|}{ Comparison } \\
\hline \multirow[t]{3}{*}{ Mulch } & \multicolumn{2}{|c|}{ Treatments } & SE (d) & $\mathrm{CD}_{0.05}$ & & & & \\
\hline & \multicolumn{2}{|c|}{ M0 vs M1 } & 1.50 & 3.14 & & & & \\
\hline & \multicolumn{2}{|c|}{$\left.\begin{array}{l}\text { M1 vs M2 } \\
\text { M1vsM3 } \\
\text { M0vsM3 } \\
\text { M0vsM2 } \\
\text { M2vsM3 }\end{array}\right\}$} & 1.18 & 2.48 & & & & \\
\hline $\begin{array}{l}\text { Thickness } \\
\text { Levels }\end{array}$ & \multicolumn{2}{|c|}{ T1vs T2 } & 1.06 & 2.22 & & & & \\
\hline $\begin{array}{l}\text { Alignment } \\
\text { Levels }\end{array}$ & \multicolumn{2}{|l|}{ I1vs I2 } & 1.50 & 3.14 & & & & \\
\hline
\end{tabular}

Fruit yield in KG/PLOT, $\mu=$ MICRONS 
Fig.1 Mean weekly soil temperature at $5 \mathrm{~cm}$ depth under different mulch and un mulched treatments

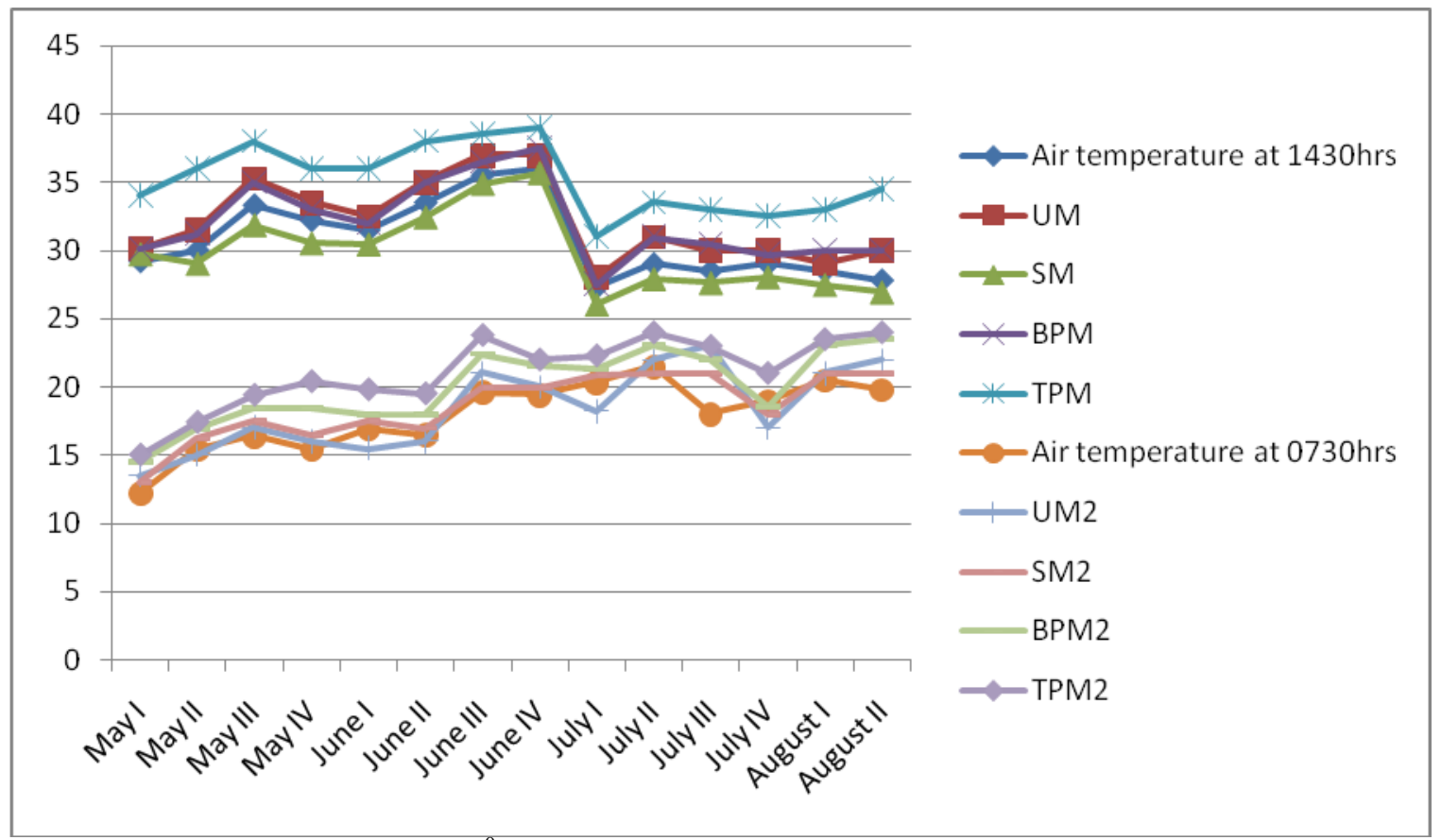

Air temperature and soil temperature at ${ }^{0} \mathrm{C}, \mathrm{UM}=$ un mulched, $\mathrm{SM}=$ straw mulch, BPM-=Black polyethylene mulch, TPM=Transparent polyethylene mulch

Fig.2 Mean weekly soil temperature at $10 \mathrm{~cm}$ depth under different mulched and un mulched treatments

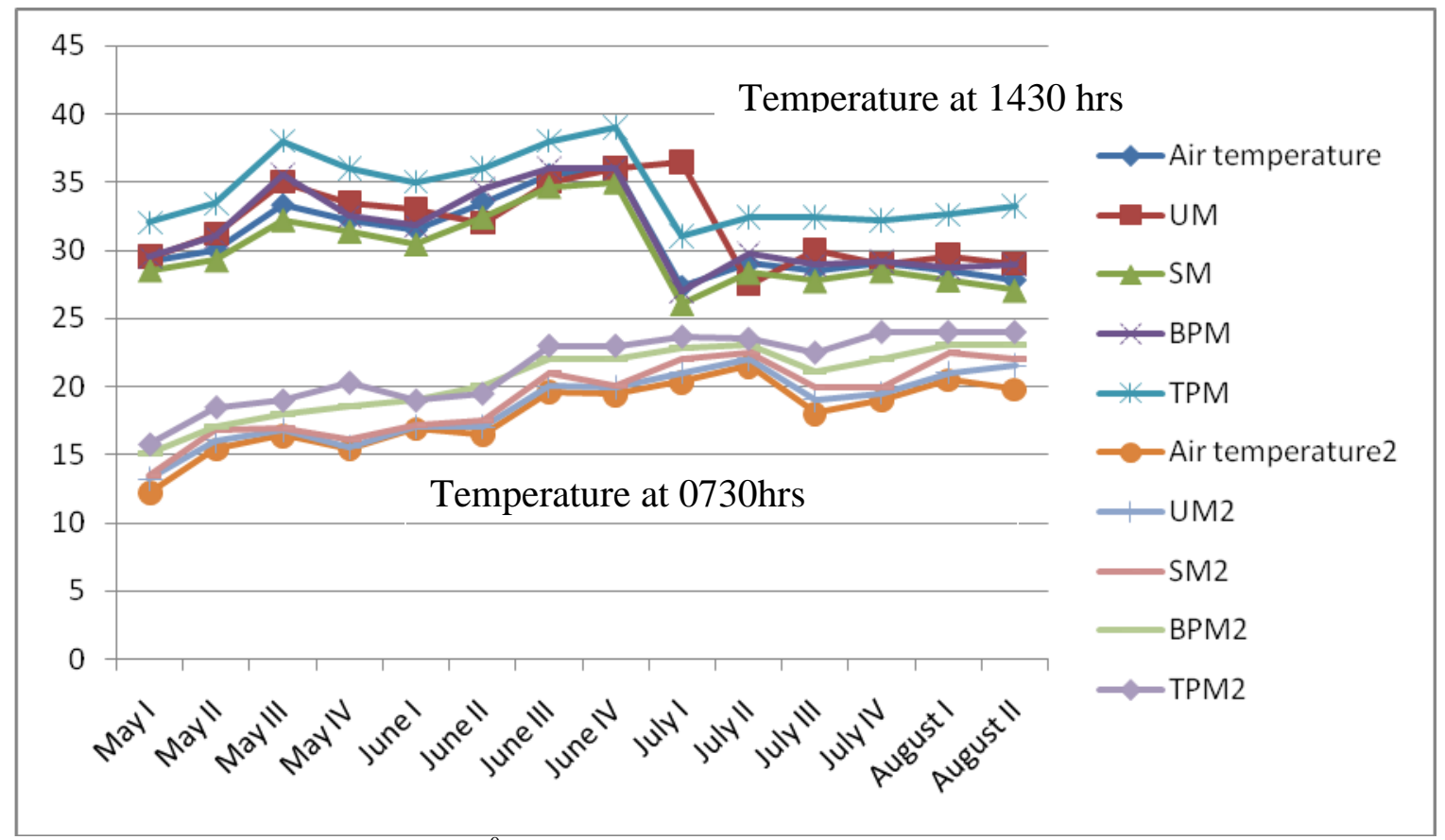

Air temperature and soil temperature at ${ }^{0} \mathrm{C}, \mathrm{UM}=$ un mulched, $\mathrm{SM}=$ straw mulch, $\mathrm{BPM}-=\mathrm{Black}$ polyethylene mulch, TPM=Transparent polyethylene mulch 
Fig.3 Influence of mulching on soil moisture content $(0-15 \mathrm{~cm})$ depth under different mulch materials for the quarterly period (May-August)

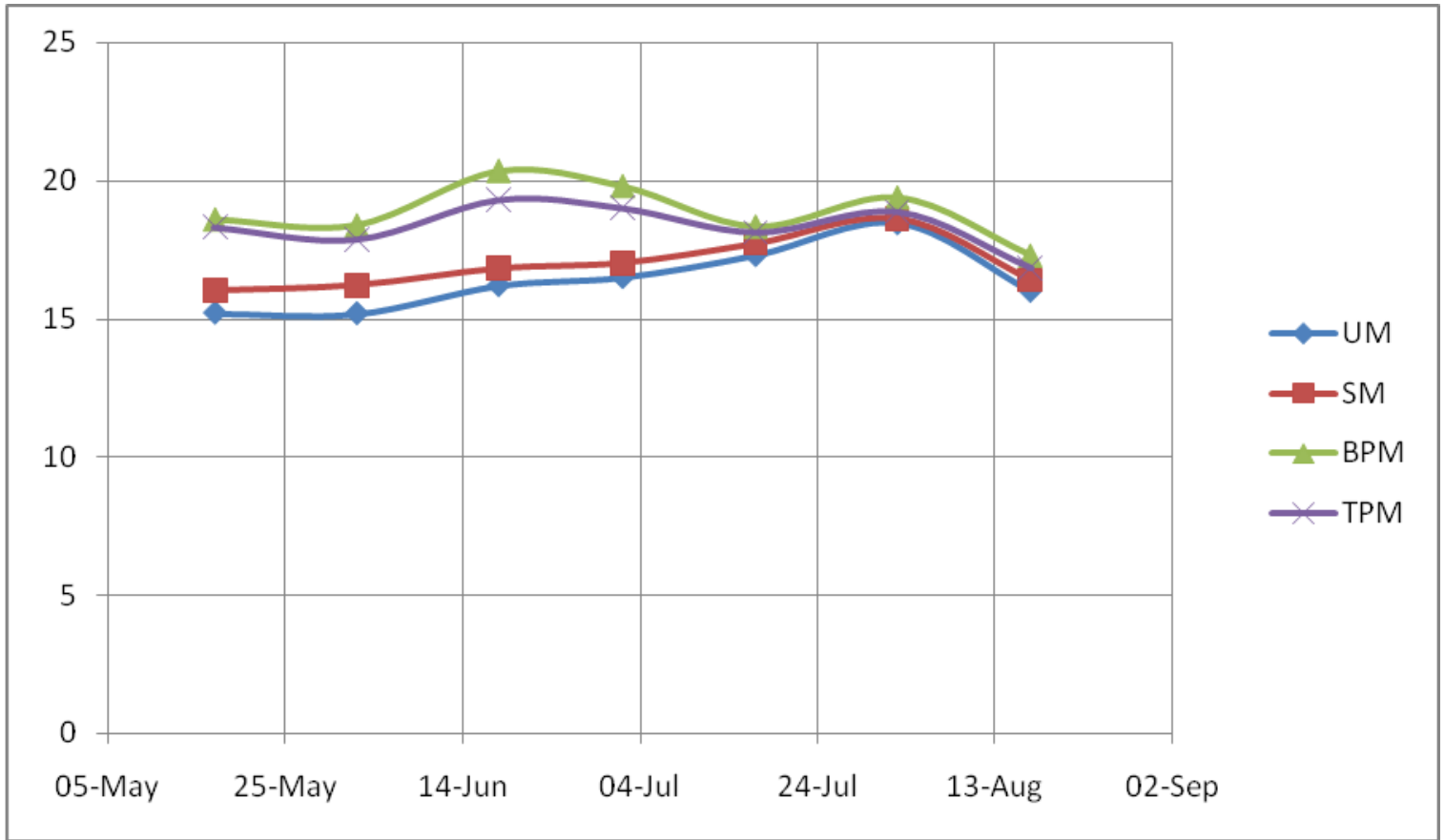

Soil Depth at $0-15 \mathrm{~cm}$ and expressed in percentage: $\mathrm{UM}=$ Unmulched, $\mathrm{SM}=$ Straw Mulch, $\mathrm{BPM}=\mathrm{Black}$ Polyethylene Mulch, TPM = Transparent Polyethylene Mulch

Application of BPM retained $13.08 \%$ higher soil moisture as compared to un mulched plots. The corresponding figures for TPM and SM were $10.47 \%$ and $3.19 \%$ moisture content as compared to UM plots (Fig. 3). The higher moisture content noted both under BPM and TPM may be due to formation of impermeable vapour barrier at soil surface as compared to SM which being porous allowed diffusion of water under vapour pressure gradient. These results are in accordance with findings of Alwis et al., (2012) who had reported significant effect on mulching on soil moisture with a moisture content of up to 10.9 $\%$ at $30 \mathrm{~cm}$ depth under various mulches treatments in pineapple. In line with the present studies, Sun et al., (2014) had reported significant improvement of soil moisture in $0-120 \mathrm{~cm}$ depth in watermelon and Teame et al., (2017) at 0-60 cm soil depth in sesame as compared to un mulched. The role of mulch thickness and alignment of polyethylene mulches was found to be nonsignificant on soil moisture content in the present investigation.

\section{Fruit yield}

The present research showed significant increase in tomato fruit yield in mulched plots as compared to un mulched. Table 2 indicates that yield/plot was found significantly higher in BPM (M2) $36.14 \mathrm{~kg} /$ plot followed by TPM (M3) with $32.15 \mathrm{~kg} / \mathrm{plot}$. UM (M0) recorded the lowest fruit yield followed by SM (M1). BPM recorded the highest yield increase of $50.66 \%$ over un mulched plots followed by TPM with $44.54 \%$ over um mulched plots. SM recorded a $22.14 \%$ increase in fruit yield over un mulched, the reason being, besides weed control, straw also acted as manure resulting in increased soil fertility. High yield under BPM as compared to other mulches may be due to favourable hydrothermal 
regime and weed free environment thereby significantly influencing the fruit set and yield. The low yield under TPM may be due to more number of weeds as compared to BPM. These results support the findings of Ogundare et al., (2015) and Sharma and Goel (2017) whom have reported maximum fruit yield in tomato and strawberry respectively under BPM as compared to other mulches. However contrary findings have been reported by Tegen et al., (2016) wherein workers have reported high fruit yield in plants mulched with straw mulch as compared to black polyethylene mulch and white polyethylene mulch. Tswanya et al., (2017) however reported non-significant fruit yield in plants mulched with various organic material. In the present studies; thickness of polyethylene mulch had played a significant role in influencing the fruit yield. Mean fruit yield data showed that $50 \mu$ thickness of BPM recorded the highest mean fruit yield of 37.70 $\mathrm{kg} /$ plot followed by $30 \mu$ thickness of BPM with a fruit yield of $34.59 \mathrm{~kg} /$ plot. $50 \mu$ thickness of both BPM and TPM was found to be statistically significant over $30 \mu$ thickness of either mulch type respectively. More moisture under $50 \mu$ thickness could have increased $\mathrm{CO}_{2}$ level thereby causing phytosynthate partioning to flowering and fruit yield (Decoteau et al., 1989). However contrary findings have been reported by Pandian et al., (2017) and Thenmozhi and Kottiswaran (2017) wherein $25 \mu$ thickness of BPM along with drip irrigation recorded higher chilli fruit yield and capsicum fruit yield as compared to $50 \mu$ thickness of BPM. Further investigations on alignment of mulch revealed that intra-row mulch alignment was significant over inter-row in both BPM and TPM. The combination studies of the subtreatments showed that $50 \mu$ thickness of BPM aligned intra row recorded the highest fruit yield of $38.67 \mathrm{~kg} / \mathrm{plot}$ followed by interrow aligned mulch of the same thickness with $36.73 \mathrm{~kg} /$ plot. Further data interpretation revealed that TPM $30 \mu$ aligned inter-row recorded lowest yield of $30.83 \mathrm{~kg} / \mathrm{plot}$ at par with TPM $50 \mu$ inter-row with $30.33 \mathrm{~kg} /$ plot.

In conclusion, the overall studies had revealed that mulches caused significant effect on the hydrothermal regime by appreciating soil moisture and soil temperature as compared to un mulched plots. Use of BPM recorded $13.08 \%$ higher soil moisture content closely followed by TPM. Polyethylene mulches had recorded raise in maximum temperature in case of TPM and increase of minimum soil temperature in BPM as compared to un mulched treatment. The resulting alteration in the hydrothermal regime had also reflected on the fruit yield. Highest fruit yield was recorded in BPM plots with a yield of 36.14 $\mathrm{kg} / \mathrm{plot}$ followed by TPM with $32.15 \mathrm{~kg} / \mathrm{plot}$. Combination studies had revealed that BPM (M2) with 50 micron thickness aligned intrarow was the best treatment in terms of fruit yield. As such under mid hills conditions of Himachal Pradesh, the practice of mulching particularly with black polyethylene mulch may be recommended for increased tomato fruit yield.

\section{Acknowledgements}

I am thankful to late Dr M.C. Thakur, Senior Vegetable Breeder, Department of Vegetable Crops, Dr Y.S. Parmar University of Horticulture and Forestry, Nauni Solan. H.P for his guidance and encouragement towards completion of the research work.

\section{References}

Abhivyakti Kumari, P., Ojha, R. K. and Job, M. 2016. Effect of plastic mulches on soil temperature and tomato yield inside and outside the polyhouse. Agricultural Science Digest., 36(4): 333-336.

Abul-Soud, M., El-Ansary, D. O. and Hussein, A. M. 2010. Effects of 
different cattle manure rates and mulching on weed control and growth and yield of squash. Journal of Applied Science Research., 6(9): 1379-1386.

Adigun, J. A. 2005. Critical period of weed interference in rainfed and irrigated tomatoes in the Nigerian savanna. Agicultura Tropica Et Subtropica., 38 (2):73-79.

Alwis, A. J. and Herath, H. 2012. Impact of mulching on soil moisture, plant growth and yield of Mauritius pineapple (Ananas comosus. L., Merr). Journal of Food and Agriculture., 2(1):15-21.

Anonymous, 2016. Horticultural Statistics at a Glance. Department of Agriculture, Cooperation and Farmers Welfare. New Delhi.

Bakht, T., Khan, I. A., Marwat, K. and Hussain, Z. 2014. Integration of row spacing, mulching and herbicides on weed management in tomato. Pakistan Journal of Botany., 46 (2): 543-547.

Decoteau, D. R., Kasperbauer, M. J. and Hunt, P. G. 1989. Mulch surface color affects yield of fresh market tomatoes. Journal of American Society for Horticultural Science., 114: 216-219

Eruola, A. O., Bello, N. J., Ufoegbune, G. C. and Makinde, A. A. 2012. Effect of mulching on soil temperature and moisture regime on emergence, growth and yield of white yam in a tropical wet-and -dry Climate. International Journal of Agriculture and Forestry., 2 (1):93-100.

Gupta, R. and Acharya, C. L. 1993.Effect of mulch induced hydrothermal regime on root growth, water use efficiency, yield and quality of strawberry. Journal of the Indian Society of Soil Science., 41:1725.

Ham, J. M., Kluitenberg, G. J. and Lamnt, W. J. 1993. Optical properties of plastic mulches affect the field temperature regime. Journal of American Society for
Horticultural Science., 118:188-193.

Jamkar, T. 2014. Studies on the effect of mulching on weed density and yield of Chilli (Capsicum annum L.). MSc (Agric.) Thesis, Jawaharlal Nehru Krishi Vishwa Vidyalaya, Jabalpur, Madhya Pradesh, India.

Kosterna, E. 2014. The effect of covering and mulching on the soil temperature, growth and yield of tomato. Folia Horticulturae., 26 (2): 91-101.

Liu, S. Y., Zhang, L.F., Jia, J. M., Fan, F. C. and Shi, Y.F. 2014. Effect of plastic mulch on soil moisture and temperature and limiting factors to yield increase for dryland spring maize in the North China. Ying Yong Sheng tai Xue Bao., 25 (11):3197-3206.

Ogundare, S. K., Babatunde, I. J. and Etukudo, O. O. 2015. Response of Tomato variety (Roma F) yield to different mulch material and staking in Kabba, Kogi state Nigeria. Journal of Agricultural Studies., 3 (2) 61-70.

Pandian, V. N., Selvamurugan, M. and Muthuchamy, I. 2017. Drip irrigation and black plastic mulching for improved productivity in chilli. International Journal of Current Microbiology and Applied Science., 6 (11):2732-2737.

Panse, V. G. and Sukhatme, P.V. 1985. Statistical Methods for agricultural workers., ICAR. New Delhi

Pramanick, M., Pal, D., Roy, A., Debnath, S. and Dwary, A. 2006. Effect of polyethylene mulches on weed management in onion. Journal of Crop and Weed., 2 (1): 20-22.

Rajablariani, H. R., Hassankhan, F. and Rafezi, R. 2012. Effect of colored plastic mulches on yield of tomato and weed biomass. International Journal of Environmental Science and Development., 3(6) 590-593.

Ramakrishna, A., Tam, H. M., Wani, S. P. 
and Long, T. D. 2006. Effect of mulch on soil temperature, moisture, weeds infestation and yield of groundnut in northern Vietnam. Field Crop Research., 95(2-3):115-125.

Sharma, V.K. and Goel, A.K. 2017.Effect of mulching and nitrogen on growth and yield of strawberry. International Journal of Science and Environment., 6 (3):2074-2079.

Sun, H. X, Wang, W., Zhang, P., Wang, Z. W., Jia, Z. K, Yang, B. P. and Han, Q. F. 2014. Effects of straw mulching on soil moisture and watermelon yield in dryland. Ying Yong Sheng tai Xue Bao., 25(7): 2014-2010.

Teame, G., Tsegay, A. and Abrha, 2017. Effect of organic mulching on soil moisture, yield and yield contributing components of Sesame (Sesamum indicum L.) International Journal of Agronomy., 2017:1-6.

Tegen, H., Dessalegn, Y. and Mohammed, W. 2016. Influence of mulching and varieties on growth and yield of tomato under polyhouse. Journal of Horticulture and Forestry., 8(1):1-11.

Thenmozhi, M. and Kottiswaran, S. V. 2017. Effect of fertigation scheduling under drip irrigation with different black polyethylene mulching in capsicum crop under poly house and open conditions. Journal of Pharmacognosy and Phytochemistry, 6(5):2485-2490.

Tswanya, M. N., Olaniyi, J. O. and Atanda, T. T. 2017. Effect of mulch material and mulching rate on fruit yield and nutritional quality of tomato (Lycopersicon lycopersicum mill) in Ogbomoso and Mokwa, Nigeria. Current trends in biomedical engineering and bioscience., 5(3)1-9.

Vinuta, B., Rajasekhar, M. and Kottiswaran, S. V. 2016. Influence of plastic mulching and fertigation levels on growth and yield of grafted brinjal (Solanum melongena L) under drip irrigation. International Journal of Advances in Agricultural Sciences and Technology., 3(7): 1-11.

\section{How to cite this article:}

Sunil A. Nair. 2018. Effect of Mulching on Hydrothermal Regime and Fruit Yield of Tomato (Lycopersicon esculentum Mill). Int.J.Curr.Microbiol.App.Sci. 7(02): 1005-1013. doi: https://doi.org/10.20546/ijcmas.2018.702.124 